AGREGAT: Jurnal Ekonomi dan Bisnis

Vol. 3, No. 1, Maret 2019

http://journal.uhamka.ac.id/index.php/agregat

p-ISSN: 2549-5658 e-ISSN: 2549-7243

DOI: 10.22236/agregat_vol3/is1pp46-57

Hal 46 - 57

\title{
THE DETERMINANTS OF SOVEREIGN CREDIT RATINGS: INDONESIA AND ITS NEIGHBORHOOD COUNTRIES 1998-2016
}

\author{
Gerry Michel, Akhmad Solikin \\ Directorate General of Budget Financing and Risk Management, Ministry of Finance \\ Polytechnic of State Finance STAN, Ministry of Finance \\ Email: michelgerry@gmail.com; akhsol@pknstan.ac.id
}

Diterima: 24 Desember 2019; Direvisi: 8 Januari 2019; Disetujui: 11 Januari 2019

\begin{abstract}
The aim of this research is to study the determinants of sovereign credit ratings of Indonesia and its neighborhood countries in the period of 1998-2016. Using secondary data and analyzed using ordered probit, it is found that every credit rating agency has its own variables influencing to its published credit ratings. In general, for Indonesia and its neighborhood countries, the variables with significant and positive relationship are fiscal balance and current account deficit to GDP, freedom index, and GDP per capita; while the variables with significant and negative relationship are external debt to GNI and real exchange rate. Gross domestic savings to GDP influences credit ratings in both ways. Interestingly, inflation does not affect the credit ratings. Indonesia and neighborhood governments could use this information to manage their macroeconomic indicators in order to get favorable ratings from credit rating agencies.
\end{abstract}

Keywords: Indonesia,Ordered Probit, Rating Agency, Sovereign Credit Rating.

\begin{abstract}
Abstrak
Tujuan penelitian ini adalah untuk mempelajari penentu peringkat kredit Negara bagi Indonesia dan negara-negara tetangga pada periode 1998-2016. Menggunakan data sekunder dan dianalisis menggunakan ordered probit, Ditemukan bahwa setiap lembaga pemeringkat kredit mempunyai variable lmasing-masing yang memengaruhiperingkatkredit yang dipublikasikan. Secara umum untuk Indonesia dan negara-negara tetangga, variabel-variabel yang signifikan dan berpengaruh positif adalah keseimbangan fiscal dand efisit transaksi berjalanter hadap PDB, indeks kebebasan, dan PDB per kapita; sedangkan variabel yang signifikan dan berpengaruhnegatif adalah utang luar negeri terhadap GNI dan nilai tuka rriil. Tabungan domestic kotor terhadap PDB memengaruhi peringkat kredit secara dua arah.Menariknya, inflasi tidak memengaruhi peringkat kredit. Pemerintah Indonesia dan negara-negara tetangga dapat menggunakan informasi ini untuk mengelolain dikatorma kro ekonomi dalam rangka memperoleh peringkat utang yang baik dari lembaga pemeringkat.
\end{abstract}

Kata Kunci: Indonesia, Ordered Probit, Lembaga Pemeringkat, Peringkat Kredit Negara. 


\section{INTRODUCTION}

Sovereign credit ratings are very important due to globalization of market and cross border investments. Sovereign credit ratings are not country ratings, but they address the credit risk of national government, do not address specific default risk of other issues (Beers \& Cavanaugh, 1998). These ratings give insight into investing risk and political risk of a particular country.

Sovereign credit ratings affect economy of a country in terms of cost of debt and foreign direct investment. For example, OECD countries received high foreign direct investment (FDI) when their credit ratings were high (Cai, Gan, \& Kim, 2018).Turkey observed two ways causality between sovereign credit ratings and FDI during 1995-2013 (Bayar \& Kilic, 2014). The downgrade of sovereign credit ratings would lead to reduction of investments and reliance of credit market due to rising cost of debt (Almeida, Cunha, Ferreira, \& Restrepo, 2017). Furthermore, the bond yield of firms is found to increase significantly due to the downgrades. For short term government borrowing cost, a downgrade to subinvestment grade by one major rating agency increase Treasury bill yields by 138 basis points, on average (Hanusch, Hassan, Algu, Soobyah, \& Kranz, 2016).

Research on determinants of sovereign credit ratings still attracts many studies up to now. One of the reasons might be credit rating agencies do not offer transparent criteria to determine ratings and their changes (Mora, 2006). Thus, many studies have been conducted in various countries in different periods. As shown in Table 1, the results of several previous studies on determinants of sovereign credit ratings are still ambiguous and inconsistent in different country studies.

Table 1. Inconsistent Results in Previous Studies

\begin{tabular}{|c|c|c|}
\hline Authors & Samples & Variables \\
\hline Cantor \& Packer & 49 countries across regions & Fiscal balance (x) \\
\hline (1996) & 86 countries across regions & Real exchange rate $(+)$; gross domestic savings $(+)$ \\
\hline $\begin{array}{l}\text { Blanc (2006) } \\
\text { Chodnicka (2015) }\end{array}$ & 45 European countries & $\begin{array}{l}\text { Gross domestic savings to GDP }(+) \text { for high \& } \\
\text { middle economies; (-) for low economies; official }\end{array}$ \\
\hline Kabadayı \& Çelik & 19 emerging countries & $\begin{array}{l}\text { exchange rates }(-) \\
\text { Account deficit \& fiscal balance to GDP (-); real }\end{array}$ \\
\hline $\begin{array}{l}\text { Pretorius \& Botha } \\
(2017)\end{array}$ & 28 African countries & Current account to GDP $(+)$; fiscal balance $(+)$ \\
\hline
\end{tabular}

Note: $(+)$ positive influence, $(-)$ negative influence, $(\mathrm{x})$ no influence

Source: Authors' compilation

Themostprominentcreditratingagencies to Malaysia, Philippines, and Thailand. are Standard \& Poor's (S\&P's), Moody's, In addition, in the period of 1998 to 2016, and Fitch. However, their credit ratings are S\&P's had not given investment grade rating different from each other. For example, in for Indonesia. Other rating agencies, such as terms of S\&P's ratings, Indonesia has the Fitch had awarded investment grade rating lowest and the most volatile grade compared for Indonesia since 2012, while Moody's had awarded it since 2011. 
Ministry of Finance Indonesia has a vision to be the main driver of inclusive economic growth for Indonesia in the $21^{\text {th }}$ century. Many research on effect of sovereign credit ratings showed the correlation between better economic conditions and higher ratings (Almeida et al., 2017; Hanusch et al., 2016) which make a policy to improve sovereign credit ratings very relevant.

The inconsistent results of previous research on different countries as exemplified in Table 1, urge an additional research with smaller scope to be conducted in the case of Indonesia. Furthermore, every credit rating agencies seems to have different consideration of rating formula that would be interesting to be studied. The addition of neighborhood countries, i.e. Malaysia, Philippines, and Thailand has two goals: (1) to compare determinants of credit ratings for Indonesia and for those of three Indonesia's neighborhood countries and (2) to fulfill minimum requirement of small sample since Indonesia data alone will not suffice. The choice of Indonesia and surrounding countries also constitutes innovation for this research since limited studies focus to this region in the study of sovereign credit ratings.

Therefore, the research question is: What are determinants of sovereign credit ratings in Indonesia and its neighborhood countries? Specifically, this research interested in macroeconomic determinants, i.e. fiscal balance and current account deficit, external debt, freedom index, GDP per capita, real exchange rates, inflation and gross domestic savings.

\section{RESEARCH METHOD}

The objects of this research are sovereign credit ratings of Indonesia and its neighborhood countries from 1998 to 2016. The selection of countries is based on data availability. Therefore, Malaysia, Thailand, and Philippines are preferably chosen rather than countries like Vietnam, Myanmar, or Cambodia. Singapore unfortunately must be excluded due to difficulty of getting its external debt record.

This research used only secondary data. The data in the form of credit ratings and macroeconomic indicators were obtained from Bloomberg terminal and World Bank site (https://data.worldbank.org).

The dependent variable in this research is sovereign credit ratings. Sovereign credit ratings are divided into two categories, i.e. investment grade and speculative grade. Investment grade reflects high grade with high credit worthiness; while speculative grade signs low grade with low credit worthiness.

The highestcredit rating, i.e. prime, is AAA in S\&P and Fitch and Aaa in Moody's system; while the lowest is $\mathrm{C}$ in all rating agencies, in addition to $\mathrm{SD}$ rating for speculative default. To change the sovereign credit ratings to become ordinal scale, the coding method by Cantor and Packer (1996) and also Kabadayi and Çelik (2015) were used. The complete rating symbols and ordinal scale were shown in Table 2. 
Table 2. Rating Symbols and Ordinal Scales

\begin{tabular}{|c|c|c|c|c|}
\hline \multirow[b]{2}{*}{ Rating Specification } & \multicolumn{3}{|c|}{ Rating Symbols } & \multirow[b]{2}{*}{ Scale } \\
\hline & $S \& P$ & Fitch & Moody's & \\
\hline \multicolumn{5}{|l|}{ Investment grade rating } \\
\hline Highest quality & AAA & AAA & Aaa & 6 \\
\hline High quality & $\mathrm{AA}+, \mathrm{AA}, \mathrm{AA}-$ & $\mathrm{AA}+, \mathrm{AA}, \mathrm{AA}-$ & $\mathrm{Aa} 1, \mathrm{Aa} 2, \mathrm{Aa} 3$ & 5 \\
\hline Strong payment capacity & $\mathrm{A}+, \mathrm{A}, \mathrm{A}-$ & $\mathrm{A}+, \mathrm{A}, \mathrm{A}-$ & $\mathrm{A} 1, \mathrm{~A} 2, \mathrm{~A} 3$ & 4 \\
\hline Adequate payment capacity & $\mathrm{BBB}+, \mathrm{BBB}, \mathrm{BBB}-$ & $\begin{array}{l}\text { BBB+, BBB, } \\
\text { BBB- }\end{array}$ & $\begin{array}{l}\text { Baa1, Baa2, } \\
\text { Baa3 }\end{array}$ & 3 \\
\hline \multicolumn{5}{|l|}{ Speculative grade rating } \\
\hline Likely to fulfill obligation & $\mathrm{BB}+, \mathrm{BB}, \mathrm{BB}-$ & $\mathrm{BB}+, \mathrm{BB}, \mathrm{BB}-$ & $\mathrm{Ba} 1, \mathrm{Ba} 2, \mathrm{Ba} 3$ & 2 \\
\hline High risk obligation & $\mathrm{B}+, \mathrm{B}, \mathrm{B}-$ & $\mathrm{B}+, \mathrm{B}, \mathrm{B}-$ & B1, B2, B3 & 1 \\
\hline Obligation cannot meet & $\begin{array}{l}\mathrm{CCC}+, \mathrm{CCC}, \mathrm{CCC}- \\
, \mathrm{CC}, \mathrm{C}, \mathrm{SD}\end{array}$ & $\begin{array}{l}\mathrm{CCC}+, \mathrm{CCC}, \\
\mathrm{CCC}-, \mathrm{CC}, \mathrm{C}, \mathrm{SD}\end{array}$ & $\begin{array}{l}\text { Caa1, Caa2, } \\
\text { Caa3, Ca, C, SD }\end{array}$ & 0 \\
\hline
\end{tabular}
Source: Cantor \& Packer (1996); Kabadayi \& Çelik (2015)

There are seven independent variables based on results of previous literature which used in this study, i.e. (1) coefficient for fiscal are expected to influence to sovereign credit balance and current account deficit to GDP ratings in Indonesia and the neighborhood (CATGDP), (2) inflation as calculated from countries. Each independent variable, its GDPdeflator(DEF),(3) External debt to gross expected sign, notation, and variable type are national income (EXDGNI), (4) freedom summarized in Table 3. More information index (FHI), (5) gross domestic product about the independent variables, including per capita (GDPPC), (6) real exchange rate formulas to operationalize the independent (REXR), and gross domestic saving to GDP variables follow. The explanation is (SAVGDP). The seven variables are chosen mainlyfromHubbard, O'Brien, and Rafferty (2011), unless stated otherwise. .

Table 3. Independent Variables

\begin{tabular}{lcll}
\hline \multicolumn{1}{c}{ Variables } & Expected Sign & Notation & Variable Type \\
\hline Coefficient of fiscal balance \& current account deficit to & - & CATGDP & Ratio \\
GDP & - & DEF & Ratio \\
Inflation & - & EXDGNI & Ratio \\
External debt to GNI & + & FHI & Interval \\
Freedom index & + & GDPPC & Ratio \\
Gross domestic product per capita & - & REXR & Interval \\
Real exchange rates & - & SAVGDP & Ratio \\
Gross domestic savings to GDP & + & &
\end{tabular}

Source: Authors' compilation 
CATGDP is computed as the ratio of fiscal balance and current account deficit as a portion of GDP, while inflation is calculated as GDP deflator. REXR is calculated as nominal exchange rates multiplied by proportion of domestic per foreign price level. Furthermore, Freedom index measures economic environment in which government can exercise control through rule of law, governmentbudgetsize, regulatory efficiency, and market openness (Miller \& Kim, 2017).

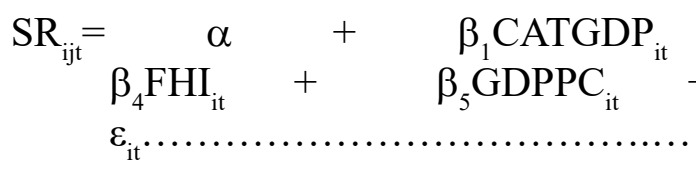

where SR stands for sovereign credit rating, $j$ represents three different sovereign credit ratings (i.e. S\&P, Moody's, and Fitch), $i$ symbolizes country, and $t$ denotes time. Thus, there are three empirical models, one for each credit rating agency to predict probability of getting certain sovereign credit ratings.

Before implementing ordered probit regression, classical assumption tests were implemented,i.e.normality,multicollinearity, autocorrelation, and heteroscedasticity test. In addition, significance tests in terms of likelihood ratio statistic, Z-statistic, and pseudo-R ${ }^{2}$ tests (Gujarati \& Porter, 2009) were implemented to inquire the robustness of independent variables in explaining the dependent variable.

As for normality test, Saphiro-Wilk and Saphiro-Francia results are 0.8393 and 0.5786 , well above 0.05 to confirm normality of residuals. For multicollinearity test, results of Pearson product moment correlation test show no multicollinearity exists. The
The index is computed as composite index consisting of property rights, government integrity, judicial effectiveness, tax burden, government spending, fiscal health, business freedom, labor freedom, monetary freedom, trade freedom, investment freedom, and financial freedom.

The model employed in this research is ordered probit regression since the dependent variable is ordinal scale.The empirical model is as follow:

$+\underset{\beta_{6} \operatorname{REXR}_{\mathrm{it}} \beta_{2 \mathrm{DEF}}+}{+} \underbrace{}_{3 \mathrm{EXDGNI}_{\mathrm{it}}}+$

highest correlations are between SAVGDP and CATGDP (0.6177), between EXDGNI and DEF (0.6036), and between REXR and EXDGNI (-0.6107). All are below 0.8 as indicator of serious multicollinearity. In addition, testing multicollinearity using VIF produces EXDGNI as the highest VIF value (3.57), which is below the VIF value of 4 to represent serious multicollinearity problem.

Regardingautocorrelation test, this study used Wooldridge test to identify autocorrelation. The result shows that the value of Prob. $>F$ is 0.0108 , below 0.05, meaning that autocorrelation exists. To cure the problem, regression was done using "vce(robust)" command in STATA. This procedure was known as White's heteroscedasticity consistent standard errors or robust standard errors(Gujarati, 2011).

Heteroscedasticity test was performed using Breusch-Pagan/Cook-Weisberg test. The result was Prob. $>$ chi $2=0.0734$, above 0.05 . It means that no heteroscedasticity in the data. 
Ordered probit model coefficient differ by a scale factor, therefore the magnitude of the coefficient cannot be interpreted directly. The interpretation of coefficient is conducted through marginal effect test (Gujarati \& Porter, 2009). Marginal effect is a measure of the instantaneous effect of a change in a particular explanatory variable on the predicted probability variable. The marginal effect tests were conducted for each rating level of each rating agency.

\section{RESULT AND DISCUSSION}

Descriptive statistics of variables are presented in Table 4. As seen in Table 4, mean sovereign credit ratings lie between 2.42 to 2.76 , out of maximum 4 . It means that mostly Indonesia and the neighborhood countries have sovereign credit ratings of 2 or 3 . Since rating 3 means the minimum base for investment grade, it implies that in general the countries in this research are under investment grade during period studied.

The coefficient of current account and fiscal balance to GDP (CATGDP) is positive, meaning the countries in the sample have positive balance of trade, investment, transfer, and government budget. As for inflation (DEF), the values range between $-5 \%$ and $75 \%$. The minimum inflation was observed in Malaysia in 2009; while the maximum inflation was observed in 1998 during economic crisis. On average, mean inflation is $6 \%$ for the countries during period of study.

Table 4.Descriptive Statistics

\begin{tabular}{lrrrrr}
\hline \multicolumn{1}{c}{ Variable } & N & \multicolumn{1}{c}{ Mean } & Std. Dev & \multicolumn{1}{c}{ Min } & \multicolumn{1}{c}{ Max } \\
\hline SR (S\&P) & 76 & 2.42 & 1.22 & 0.00 & 4.00 \\
SR (Moody's) & 76 & 2.59 & 0.97 & 1.00 & 4.00 \\
SR (Fitch) & 76 & 2.76 & 0.92 & 1.00 & 4.00 \\
CATGDP & 76 & 0.03 & 0.06 & -0.06 & 0.23 \\
DEF & 76 & 0.06 & 0.09 & -0.05 & 0.75 \\
EXDGNI & 76 & 0.48 & 0.24 & 0.20 & 1.68 \\
FHI & 76 & 61.17 & 4.91 & 51.90 & 71.5 \\
GDPPC & 76 & $3,706.18$ & $2,756.82$ & 463.97 & $11,183.96$ \\
REXR & 76 & 92.90 & 10.21 & 65.76 & 116.26 \\
SAVGDP & 76 & 0.30 & 0.10 & 0.14 & 0.49 \\
\hline
\end{tabular}

Source: Compiled by authors

External debt to GNI (EXDGNI)depicts lowest burden was observed in Philippines the ratio of debt owned by the country and in 2003 and the highest burden was observed its national income. The positive sign of EXDGNI shows that the countries in this in Indonesia during 1998 economic crisis.

Mean freedom index (FHI) for the study always have external debt; while the sample is 61.17 out of maximum 100, with 
AGREGAT: Jurnal Ekonomi dan Bisnis

Vol. 3, No. 1, Maret 2019

http://journal.uhamka.ac.id/index.php/agregat

p-ISSN: 2549-5658 e-ISSN: 2549-7243

DOI: 10.22236/agregat_vol3/is1pp46-57

Hal 52

the minimum was 51.9 for Indonesia in 2006 and the highest is 71.5 for Malaysia in 2016. In addition, GDP per capita (GDPPC) maximum is USD11,183.96 for Malaysia in 2014 while the minimum is USD463.97 for Indonesia in 1998.

Real effective exchange rate (REXR) measures the value of currency against weighted average of several foreign currency divided by price deflator/index of cost. Again, the lowest REXR is observed in Indonesia during economic crisis, while the highest is observed in Philippines in 2015.

As for domestic savings per GDP

government spending, and net export as a percentage of GDP.The highest SAVGDP was possessed by Malaysia in 1998, while the lowest occurred in Philippines in 1998.

The ordered probit regression results for each rating agency are presented in Table 5. As shown in the table, all models are significant at $1 \%$ as showed by Prob.>chi2 which are very low (0.000). Pseudo R2 are also high, i.e. 0.6981 for S\&P model, 0.7306 for Moody's model, and 0.7071 for Fitch model. However, Pseudo R2 is second in important for probit model as the most (SAVGDP), it represents investment, coefficient (Gujarati, 2011).

Table 5.Ordered Probit Regression Estimates

\begin{tabular}{|c|c|c|c|c|c|c|c|c|c|}
\hline \multirow[b]{2}{*}{ Variable } & \multicolumn{3}{|c|}{ S\&P } & \multicolumn{3}{|c|}{ Moody's } & \multicolumn{3}{|c|}{ Fitch } \\
\hline & Coeff & Z-stat & & Coeff & Z-stat & & Coeff & Z-stat & \\
\hline CATGDP & 29.947 & 6.77 & $* * *$ & 6.431 & 1.27 & & 11.166 & 2.76 & $* * *$ \\
\hline DEF & 3.681 & 1.23 & & 2.395 & 0.90 & & -6.930 & -1.31 & \\
\hline EXDGNI & -1.713 & -0.78 & & -0.045 & -2.99 & $* * *$ & -5.150 & -2.64 & $* * *$ \\
\hline FHI & 0.383 & 4.78 & $* * *$ & 0.349 & 4.20 & $* * *$ & 0.256 & 3.74 & $* * *$ \\
\hline GDPPC & 0.002 & 3.86 & $* * *$ & 0.002 & 5.33 & $* * *$ & 0.001 & 3.27 & $* * *$ \\
\hline REXR & -0.054 & -2.18 & $* *$ & -0.069 & -2.84 & $* * *$ & 0.014 & 0.48 & \\
\hline SAVGDP & -13.063 & -3.45 & $* * *$ & 1.271 & 0.46 & & 10.253 & 2.73 & $* * *$ \\
\hline $\begin{array}{l}\text { Observation } \\
\text { Prob.>chi2 } \\
\text { Pseudo R2 }\end{array}$ & $\begin{array}{r}76 \\
0.000 \\
0.6981 \\
\end{array}$ & & & $\begin{array}{r}76 \\
0.000 \\
0.7306 \\
\end{array}$ & & & $\begin{array}{r}76 \\
0.000 \\
0.7071 \\
\end{array}$ & & \\
\hline
\end{tabular}

Note: $* * *=\operatorname{sig} .1 \%, * *=$ sig. $5 \%, *=$ sig. $10 \%$

Source: Compiled by authors

For coefficient for fiscal balance and is in line with Pretorius and Botha (2017) current account deficit to GDP (CATGDP), it which report positive relationship between is significant at $1 \%$ in S\&P and Fitch models. current account to GDP and fiscal balance The sign is positive, which is in contrary to expectation as stipulated in Table 3. This result is different from Kabadayi and Çelik (2015) which observe negative relationship between CATGDP to sovereign credit ratings in 19 emerging economies. The result to sovereign credit ratings of 28 African countries. Thus, the sovereign credit ratings of S\&P's and Fitch will be upgraded if fiscal balance and current account deficit to GDP increase. However, Moody's rating is not affected by the CATGDP variable. 
For inflation variable which is measured using GDP deflator (DEF), it is not significant in all three models. Previous results generally observe negative relationship between inflation and sovereign credit ratings (Cantor \& Packer, 1996; Chodnicka, 2015; Kabadayi \& Çelik, 2015; Kalloub, Kapusuzoglu, \& Ceylan, 2018; Mellios \& Paget-Blanc, 2006; Pretorius \& Botha, 2017).

Regarding variable of external debt to GNI (EXDGNI), the variable is significant in Moody's and Fitch models. The variable has negative coefficient as expected. This result is in accordance with previous studies(Cantor \& Packer, 1996; Kabadayi \& Çelik, 2015; Melki, Ftiti, \& Ben Arab, 2017; Mellios \& Paget-Blanc, 2006). Arefjevs and Braslins (2013) using slightly different measure, i.e. external debt to export ratio, also found that the variable has negative sign.Therefore, to increase credit ratings, especially from Moody's and Fitch, Indonesia and its neighborhood countries should reduce their external debt to GNI.

For freedom index, the variable is significant in all models and has positive sign as expected. The result is in line with Kabadayi and Çelik (2015).Calcagno and Benefield (2013)and Belasen, Hafer, and Jategaonkar (2015)also found positive relationship between economic freedom and bond ratings in 39 states and 50 states, respectively. Thus, countries with high economic freedom enjoy favorable bond ratings and pay lower borrowing costs. Similar situation may also be able to be inferred for sovereign credit ratings.
Regarding GDP per capita (GDPPC) and sovereign credit rating, the variable is significant in all three models. It has positive sign as expected. The result confirms previous studies (Kabadayi \& Çelik, 2015; Melki et al., 2017).

The sixth independent variable, i.e. real exchange rate (REXR) is significant in S\&P and Moody's models. It shows negative signs, as expected, meaning that exchange rate depreciation leads to worse sovereign credit ratings. It is in line with Chodnicka (2015) and Kabadayi and Çelik (2015) but is contrary to Mellios and Paget-Blanc (2006). Therefore, a country in the sample should maintain its real exchange rate to get favorable sovereign credit ratings.

The last independent variable, i.e. gross domestic saving to GDP (SAVGDP) is significantin S\&PandFitchmodels. However, the coefficient has negative sign for S\&P but positive sign for Fitch model. The positive sign is reported in Kabadayi and Çelik (2015), while positive and negative signs are also observed in literature (Chodnicka, 2015; Mellios \& Paget-Blanc, 2006). Possible explanation could be difference in the level of economic development among sample. Chodnicka (2015) found that middle economic countriesin Europe have positive signs while low economic countries have negative signs.

As for marginal effect, Table 6, Table 7, and Table 8 report marginal effect for S\&P, Moody's, and Fitch, respectively. Interpretations are provided only for significant independent variables. 
AGREGAT: Jurnal Ekonomi dan Bisnis

Vol. 3, No. 1, Maret 2019

http://journal.uhamka.ac.id/index.php/agregat

p-ISSN: 2549-5658 e-ISSN: 2549-7243

DOI: 10.22236/agregat_vol3/is1pp46-57

Hal 54

Table 6.Marginal Effects for S\&P Model

\begin{tabular}{|c|c|c|c|c|c|c|c|c|c|c|c|}
\hline Variables & Sig. & $\mathrm{SR}=0$ & $\mathrm{P}>|\mathrm{z}|$ & $\mathrm{SR}=1$ & $\mathrm{P}>|\mathrm{z}|$ & $\mathrm{SR}=2$ & $\mathrm{P}>|\mathrm{z}|$ & $\mathrm{SR}=3$ & $\mathrm{P}>|\mathrm{z}|$ & $\mathrm{SR}=4$ & $\mathrm{P}>|\mathrm{z}|$ \\
\hline CATGDP & $* * *$ & $\begin{array}{r}-7.04 \mathrm{e}- \\
07\end{array}$ & 0.85 & -0.0002 & 0.78 & -1.3978 & 0.44 & 1.3966 & 0.44 & 0.0014 & 0.76 \\
\hline DEF & & $\begin{array}{r}-8.65 \mathrm{e}- \\
08\end{array}$ & 0.85 & -0.0000 & 0.79 & -0.1718 & 0.53 & 0.1716 & 0.53 & 0.0002 & 0.77 \\
\hline EXDGNI & & $\begin{array}{r}4.03 \mathrm{e}- \\
08\end{array}$ & 0.86 & 0.0000 & 0.80 & 0.0780 & 0.60 & -0.0799 & 0.60 & -0.0001 & 0.78 \\
\hline FHI & $* * *$ & $\begin{array}{r}-9.01 \mathrm{e}- \\
09\end{array}$ & 0.85 & $\begin{array}{r}-2.62 \mathrm{e}- \\
06\end{array}$ & 0.79 & -0.0179 & 0.48 & 0.0179 & 0.48 & 0.0000 & 0.77 \\
\hline GDPPC & $* * *$ & $\begin{array}{r}-3.62 \mathrm{e}- \\
11\end{array}$ & 0.85 & $\begin{array}{r}-1.05- \\
08\end{array}$ & 0.78 & -0.0001 & 0.41 & 0.0001 & 0.41 & $\begin{array}{c}7.34 \mathrm{e}- \\
08\end{array}$ & 0.76 \\
\hline REXR & $* *$ & $\begin{array}{r}1.27 \mathrm{e}- \\
09\end{array}$ & 0.85 & $\begin{array}{r}3.70 \mathrm{e}- \\
07\end{array}$ & 0.78 & 0.0025 & 0.44 & -0.0025 & 0.44 & $\begin{array}{c}-2.57 \mathrm{e}- \\
06\end{array}$ & 0.76 \\
\hline SAVGDP & $* * *$ & $\begin{array}{r}3.07 \mathrm{e}- \\
07\end{array}$ & 0.85 & 0.0001 & 0.78 & 0.6098 & 0.45 & -0.6092 & 0.45 & -0.0006 & 0.77 \\
\hline
\end{tabular}

Note: $* * *=$ sig. $1 \%, * *=$ sig. $5 \%, *=$ sig. $10 \%$

Source: Compiled by authors

In Table 6, marginal effect analysis for payment capacity $(\mathrm{SR}=3)$ increases at the S\&P model is limited to significant variables, ratio 1.3966. Focusing on having adequate i.e. CATGDP, FHI, GDPPC, REXR, and payment capacity $(\mathrm{SR}=3)$ column, 1\% SAVGDP. Analysis is also limited to increase in CATGDP, FHI, GDPCC will substantial marginal effect (marked with increase probability of getting "having shaded cells). The highest marginal effect is adequate payment capacity", whereas 1\% CATGDP, meaning that increase of coefficient increase in REXR and SAVGDP reduces of fiscal balance and current account deficit probability of getting "having adequate by $1 \%$ the probability of having adequate payment capacity" $(\mathrm{SR}=3)$ by 0.0025 point and 0.6092 point, respectively.

Table 7.Marginal Effects for Moody's Model

\begin{tabular}{lccccccccc}
\hline Variables & Sig. & $\mathrm{SR}=1$ & $\begin{array}{c}\mathrm{P}> \\
|\mathrm{z}|\end{array}$ & $\mathrm{SR}=2$ & $\begin{array}{c}\mathrm{P}> \\
|\mathrm{z}|\end{array}$ & $\mathrm{SR}=3$ & $\begin{array}{c}\mathrm{P}> \\
|\mathrm{z}|\end{array}$ & $\mathrm{SR}=4$ & $\begin{array}{c}\mathrm{P}> \\
|\mathrm{z}|\end{array}$ \\
\hline CATGDP & & $-2.77 \mathrm{e}-06$ & 0.82 & -0.2219 & 0.33 & 0.2218 & 0.33 & 0.0001 & 0.81 \\
DEF & & $-1.03 \mathrm{e}-06$ & 0.82 & -0.0826 & 0.47 & 0.0826 & 0.47 & 0.0000 & 0.80 \\
EXDGNI & $* * *$ & $1.96 \mathrm{e}-08$ & 0.82 & 0.0016 & 0.37 & -0.0016 & 0.37 & $-7.68 \mathrm{e}-07$ & 0.80 \\
FHI & $* * *$ & $-1.50 \mathrm{e}-07$ & 0.82 & -0.0120 & 0.36 & 0.0120 & 0.36 & $5.90 \mathrm{e}-06$ & 0.80 \\
GDPPC & $* * *$ & $-6.81 \mathrm{e}-10$ & 0.82 & -0.0001 & 0.33 & 0.0000 & 0.33 & $2.67 \mathrm{e}-08$ & 0.80 \\
REXR & $* * *$ & $2.96 \mathrm{e}-08$ & 0.82 & 0.0024 & 0.34 & -0.0024 & 0.34 & $-1.16 \mathrm{e}-06$ & 0.80 \\
SAVGDP & & $-5.47 \mathrm{e}-07$ & 0.85 & -0.0439 & 0.72 & 0.0439 & 0.72 & 0.0000 & 0.83 \\
\hline NOte: & & & & &
\end{tabular}

Note: $* * *=$ sig. $1 \%, * *=$ sig. $5 \%, *=$ sig. $10 \%$

Source: Compiled by authors 
Table 8.Marginal Effects for Fitch Model

\begin{tabular}{lccccccccc}
\hline Variables & Sig. & $\mathrm{SR}=1$ & $\begin{array}{c}\mathrm{P}> \\
|\mathrm{z}|\end{array}$ & $\mathrm{SR}=2$ & $\begin{array}{c}\mathrm{P}> \\
|\mathrm{z}|\end{array}$ & $\mathrm{SR}=3$ & $\begin{array}{c}\mathrm{P}> \\
|\mathrm{z}|\end{array}$ & $\mathrm{SR}=4$ & $\begin{array}{c}\mathrm{P}> \\
|\mathrm{z}|\end{array}$ \\
\hline CATGDP & $* * *$ & $-3.50 \mathrm{e}-06$ & 0.84 & -1.8082 & 0.04 & 1.7962 & 0.04 & 0.0120 & 0.64 \\
DEF & & $2.17 \mathrm{e}-06$ & 0.84 & 1.1221 & 0.37 & -1.1147 & 0.37 & -0.0075 & 0.65 \\
EXDGNI & $* * *$ & $1.62 \mathrm{e}-06$ & 0.84 & 0.8340 & 0.14 & -0.0204 & 0.14 & -0.0055 & 0.63 \\
FHI & $* * *$ & $-8.02 \mathrm{e}-08$ & 0.84 & -0.0414 & 0.06 & 0.0411 & 0.06 & 0.0003 & 0.63 \\
GDPPC & $* * *$ & $-1.94 \mathrm{e}-10$ & 0.84 & -0.0001 & 0.02 & 0.0001 & 0.02 & $\begin{array}{c}6.66 \mathrm{e}- \\
07\end{array}$ & 0.64 \\
REXR & & $-4.25 \mathrm{e}-09$ & 0.85 & -0.0021 & 0.66 & 0.0022 & 0.66 & 0.0000 & 0.74 \\
SAVGDP & $* * *$ & $-3.22 \mathrm{e}-06$ & 0.84 & -1.6602 & 0.17 & 1.6492 & 0.17 & 0.0110 & 0.63 \\
\hline NOte: & & & & & & & &
\end{tabular}

Note: $* * *=$ sig. $1 \%, * *=$ sig. $5 \%, *=$ sig. $10 \%$

Source: Compiled by authors

In Table 7, the highest marginal effect for

Moody's model is freedom index, CONCLUSION

meaning that $1 \%$ increase in freedom index will increase probability of getting "having adequate payment capacity" $(\mathrm{SR}=3)$ by 0.0120 point. In brief, $1 \%$ increase in freedom index and GDP per capita will bring higher probability to be granted "having adequate payment capacity" $(\mathrm{SR}=3)$. Conversely, $1 \%$ increase in real exchange rates and external debt will decrease probability of getting $\mathrm{SR}=3$, or in other words increase probability of getting $\mathrm{SR}=2$, i.e. "likely to fulfill obligation".

In Table 8 for Fitch Model, $1 \%$ increase in fiscal balance and current account will have higher probability to get rating "strong payment capacity" $(\mathrm{SR}=4)$ by 0.0120 point. In addition, $1 \%$ increase in freedom index, saving to GDP, and GDP per capita will increase probability of getting $\mathrm{SR}=3$; while $1 \%$ increase in external debt will decrease probability of getting $\mathrm{SR}=3$ rating or increase probability of getting $\mathrm{SR}=2$ rating. Focusing on column $\mathrm{SR}=3$, the highest marginal effect is saving to GDP (SAVGDP).
Determinants of sovereign credit ratings for Indonesia, Malaysia, Thailand, and Philippines are fiscal balance and current account, external debt, freedom index, GDP per capita, real exchange rates, and gross domestic savings. Inflation does not determine the sovereign credit ratings in these countries.

From marginal effect tests, it is found that every variable has different effect to each rating agency. $\mathrm{S} \& \mathrm{P}$ rating is most affected by fiscal balance and current account to GDP, Moody's rating is affected the most by freedom index, and Fitch rating is affected mainly by gross domestic saving to GDP.

For government and policy makers in Indonesia and its neighborhood countries alike, to get favorable sovereign credit ratings and thus lower borrowing costs, the governments should set up policies and manage macro economies. Specifically, they should increase fiscal balance, increase current account, lower external debt, maintain freedom index, increase GDP per 
AGREGAT: Jurnal Ekonomi dan Bisnis

Vol. 3, No. 1, Maret 2019

http://journal.uhamka.ac.id/index.php/agregat

p-ISSN: 2549-5658 e-ISSN: 2549-7243

DOI: 10.22236/agregat_vol3/is1pp46-57

Hal 56

capita, and appreciate real exchange rates. As for gross domestic savings to GDP, it should be treated cautiously since the impact to sovereign credit ratings is ambiguous.

Limitation for this study is mainly due to small sample. For future study, researcher could add more observations since this study use limited 76 observations. Addition of data, however, may force researcher to include several countries, since time series of individual country may not suffice. Moreover, applying more stringent multicollinearity test may be able to cure many insignificant marginal effects. Furthermore, using other independent variables may add prediction power of the model.For example, an interesting research avenue is using technological development to explain sovereign credit rating, such as using mobile phone as measure of knowledge economy (Bissoondoyal-Bheenick, Brooks, \& Yip, 2006). Other independent variables are political stability or corruption control as measures which similar to freedom index (Kalloub et al., 2018). Researcher may also use other dependent variables, such as state bond ratings(Belasen et al., 2015; Calcagno $\&$ Benefield, 2013) or spread between state bonds and risk free bonds (Pačebutaite, 2011).

\section{REFERENCE}

Almeida, H., Cunha, I., Ferreira, M. A., \& Restrepo, F. (2017). The real effects of credit ratings: The sovereign ceiling channel. The Journal of Finance, 72(1), 249-290. http://doi.org/10.1111/ jofi. 12434 .

Arefjevs, I., \& Braslins, G. (2013). Determinants of sovereign credit ratings: Example of Latvia. In New Challenges of Economic and Business Development (pp. 67-76). Riga: University of Latvia.

Bayar, Y., \& Kilic, C. (2014). Effects of sovereign credit ratings on foreign direct investment inflows: Evidence from Turkey. Journal of Applied Finance \& Banking, 4(2), 91-109.

Beers, D. T., \& Cavanaugh, M. (1998). Sovereign credit ratings: A primer. New York: Standard \& Poor.

Belasen, A. R., Hafer, R. W., \& Jategaonkar, S. P. (2015). Freedom and state bond ratings. Contemporary Economic Policy, 33(4), 668-677. http://doi. org/10.1111/coep. 12098

Bissoondoyal-Bheenick, E., Brooks, R., \& Yip, A. Y. N. (2006). Determinants of sovereign ratings: A comparison of case-based reasoning and ordered probit approaches. Global Finance Journal, 17(1), 136-154. http://doi. org/10.1016/j.gfj.2006.06.001

Cai, P., Gan, Q., \& Kim, S.-J. (2018). Do sovereign credit ratings matter for foreign direct investments? Journal of International Financial Markets, Institutions andMoney, 55,50-64.http:// doi.org/10.1016/j.intfin.2018.01.003

Calcagno, P. T., \& Benefield, J. D. (2013). Economic freedom, the cost of public borrowing, and state bond ratings. Journal of Financial Economic Policy, 5(1), 72-85. http://doi. org/10.1108/17576381311317790 
Cantor, R., \& Packer, F. (1996). Determinants and impacts of sovereign credit ratings. The Journal of Fixed Income, 6(3), 7691.

Chodnicka, P. (2015). Credit rating determinants for European countries. Global Journal of Management and Business Research: C Finance, 15(9), $1-35$.

Gujarati, D. (2011). Econometrics by example. New York: Palgrave Macmillan.

Gujarati, D. N., \& Porter, D. C. (2009). Basic econometrics (5th ed.). Boston: McGraw-Hill/Irwin.

Hanusch, M., Hassan, S., Algu, Y., Soobyah, L., \& Kranz, A. (2016). The ghost of a rating downgrade: What happens to borrowing costs when a government loses its investment grade credit rating?MFM Global Practice Discussion Paper (Vol. 13). Washington.

Hubbard, R. G., O’Brien, A. P., \& Rafferty, M. (2011). Macroeconomics. Boston: Pearson.

Kabadayi, B., \& Çelik, A. A. (2015). Determinants of sovereign rating in emerging countries: A qualitative, dependent variable panel data analysis. International Journal of Economics and Financial Issues, 5(3), 656-662.

Kalloub, M., Kapusuzoglu, A., \& Ceylan, N. B. (2018). The impact of Basel III adoption by $\mathrm{G} 20$ members on their credit ratings. Eurasian Journal of Economics and Finance, 6(1), 47-55. http://doi. org/10.15604/ejef.2018.06.01.005
Melki, A., Ftiti, Z., \& Ben Arab, M. (2017). Study of sovereign credit rating determinants with Bayesian approach. In 34th Symposium on Money, Banking and Finance. Paris: Université Paris Ouest Nanterre La Défense.

Mellios, C., \& Paget-Blanc, E. (2006). Which factors determine sovereign credit ratings? The European Journal of Finance, 12(4), 361-377. http://doi. org/10.1080/13518470500377406

Miller, T., \& Kim, A. B. (2017). Index of Economic Freedom 2017. Washington: The Heritage Foundation.

Mora, N. (2006). Sovereign credit ratings: Guilty beyond reasonable doubt? Journal of Banking and Finance, 30(7), 2041-2062. http://doi.org/10.1016/j. jbankfin.2005.05.023

Pačebutaitè, A. (2011). Key determinants of Lithuania's sovereign credit rating. Ekonomika, 90(1), 73-84.

Pretorius, M., \& Botha, I. (2017). Determinants of sovereign credit ratings in Africa: A regional perspective. Advances in Applied Economic Research. Springer Proceedings in Business and Economics, 549-563. 